ISSN: 1838-2959

Volume 1, Number 1, pp. 1-20

July - 2010

\title{
Transition pedagogy: A third generation approach to FYE - A case study of policy and practice for the higher education sector
}

Sally Kift

ALTC Senior Fellow and Discipline Scholar: Law

Queensland University of Technology (QUT)

Karen Nelson

Director, First Year Experience Program, QUT

John Clarke

Adjunct Professor and Senior Research Coordinator

First Year Experience Program, QUT

\begin{abstract}
Current research and practice related to the first year experience (FYE) of commencing higher education students are still mainly piecemeal rather than institution-wide with institutions struggling to achieve cross-institutional integration, coordination and coherence of FYE policy and practice. Drawing on a decade of FYE-related research including an ALTC Senior Fellowship and evidence at a large Australian metropolitan university, this paper explores how one institution has addressed that issue by tracing the evolution and maturation of strategies that ultimately conceptualize FYE as "everybody's business." It is argued that, when first generation co-curricular and second generation curricular approaches are integrated and implemented through an intentionally designed curriculum by seamless partnerships of academic and professional staff in a whole-of-institution transformation, we have a third generation approach labelled here as transition pedagogy. It is suggested that transition pedagogy provides the optimal vehicle for dealing with the increasingly diverse commencing student cohorts by facilitating a sense of engagement, support and belonging. What is presented here is an example of transition pedagogy in action.
\end{abstract}

\section{Please cite this article as:}

Kift, S., Nelson, K. \& Clarke, J. (2010). Transition Pedagogy: A third generation approach to FYE - A case study of policy and practice for the higher education sector. The International Journal of the First Year in Higher Education, 1(1), 1-20.

This article has been peer reviewed and accepted for publication in Int J FYHE. Please see the Editorial Policies under the 'About' section of the Journal for further information.

(C) Copyright of articles is retained by author/s. As an open access journal, articles are free to use, with proper attribution, in educational and other non-commercial settings. ISSN: 1838-2959 


\section{The first tertiary year}

First year higher education students attract an inordinate amount of interest and attention from researchers, administrators and practitioners. As a consequence, an impressive body of research, practice, and policy designed to enhance the first year experience (FYE) of students has been generated, generally with the underlying aims of improving student success, retention and engagement. While many of the factors influencing these behaviours are personal-for example, how students finance their studies and their lack of personal commitment to study (Yorke, 2006; Yorke \& Longden, 2008) - the responsibility for student retention and engagement does not reside solely with commencing students: institutions and their teaching and support staff have an obligation to provide the necessary "conditions, opportunities and expectations" for such engagement to occur (Coates, 2005, p. 26). Similar sentiments have also been expressed more recently by Bradley, Noonan, Nugent and Scales (2008), Gillard (2010) and Tinto (2009).

Consistent with this view, Reason, Terenzini and Domingo $(2005,2007)$ have argued that the personal, social and academic competences of students have to be addressed by institutionally-initiated engagement activities. Reflecting this, as any scan of FYE-related journals and conference proceedings attests, there are many reported pockets of excellence in individual institutions and in various discrete programs and subjects of study. However, as Krause and her colleagues noted in 2005, this essentially "piecemeal approach" of discrete first year initiatives is rarely if ever linked across an institution and "effort now needs to be directed at moving practice towards more holistic and sustainable institution-wide approaches and enhancements" (Krause, Hartley, James \& McInnis, 2005, g[8.8.6).

In 2010, despite earnest endeavours, five years on from that observation, it continues to be the case that "piecemeal" rather than "whole-of-institution" is the most apposite descriptor of the FYE initiatives reported nationally and internationally. Institutions still struggle with cross-institutional integration, coordination and coherence, in the shadow of concerning evidence suggesting that the quality of the student experience may vary more within than between institutions (Kuh, 2007). The challenge of "bridging the gaps between academic, administrative and support programs" (McInnis, 2003, p. 13) remains significant. Tinto (2006-2007) has recently observed that "substantial gains in student retention have been hard to come by ... [and] there is much that we have not yet done to translate our research and theory into effective practice" (p. 2). This is particularly evident as regards our efforts to assure coherent and coordinated institution-wide FYE approaches for all students in a massified sector.

Addressing Tinto's imperative, this discussion proposes that a "transition pedagogy" (Kift \& Nelson, 2005) is a conceptualisation that has the optimal capacity to deliver an integrated and holistic FYE, when intentionally designed first year curriculum is harnessed to mediate the learning experiences of diverse commencing cohorts. To support this claim, we draw on policy and practice innovations and evidence that are available in our own institution, the Queensland University of Technology (QUT), in Brisbane, Australia. Swing (2003) has cautioned that embedded institutional change may take as long as ten years to effect. Coincidently, Kift (2008) has noted that "in Australia, the status of the FYE, as an area deserving of concerted institutional attention, has undoubtedly grown exponentially over the last decade" (p. 2). In this context, it is both timely and appropriate to take an evolutionary view of what has happened over the last decade as QUT's FYE program has matured. As 
action learning research, we suggest our findings may be instructive, while the models and various initiatives described here may be practical approaches on which others can build in growing and refining their own institution's policy, practice and procedures.

\section{The evolution of the first year experience at the Queensland University of Technology}

\section{Setting the context}

Context is important and in terms of the FYE, individual institutional context is a vital component in constructing a fit-for-purpose framework that evidences commitment to student learning and engagement. QUT is an Australian university with an applied emphasis in programs and research, and with the branding (and consequent student expectation) of being "a university for the real world" offering programs with clear vocational relevance and strong links to industry. Spread over three campuses in Brisbane, it has around 40,000 students, including 6,000 from overseas. Each year, more than 8,000 undergraduate students make the transition to first year higher education learning in QUT's programs of study, many doing so in double degree programs across two disparate disciplines.

The QUT Blueprint ${ }^{1}$ (Queensland University of Technology [QUT], 2008), the University's five-year institutional strategic plan, outlines QUT's vision and goals for the future. The first of these is "to provide outstanding learning environments and programs that lead to excellent outcomes for graduates, enabling them to work in and guide a world characterised by increasing change" (p. 3). In 2002, a tangible manifestation of QUT's vision of providing "outstanding learning environments and programs" occurred when it invested in resources aimed at improving the experience of commencing students by initiating the First Year Experience Program (FYEP)

\section{Laying the foundation: The First Year Experience Program}

The period from 2002 to 2005 was a particularly fertile and revelatory period in conceptualising the FYE at QUT and it began with the establishment of the FYEP. Its aim was to reduce avoidable attrition and to maximise learning and engagement amongst commencing students, and it was based on two beliefs summarised at that time by Kift (2004) as:

(i) Students must be engaged primarily as learners if they are to have a successful university experience. The informal curriculum of social and community interactions, and external commitments such as work and family need to be acknowledged, incorporated and supported, but it is within the formal or academic curriculum that students must find their places, be inspired and excited, and work towards mastery of their chosen area. And:

(ii) Students in their first year have special learning needs arising from the social and academic transition they are experiencing. From multiple starting points, all students are on a journey to becoming self-managing or self-directed learners and the first-year curriculum must help get them there. (p. 5)

\footnotetext{
${ }^{1}$ Currently under revision.
} 
In 2002, one of the first activities undertaken by a then loose collective of cross-institutional staff responsible for the FYEP was to develop three "Issues Papers" (QUT, 2002a, 2002b, 2002c). These were used to stimulate discussion within the QUT community around the identification of commencing students' transition needs and adjustment challenges, and to take the first steps towards setting the agenda for improving students' early engagement with their new learning in the institution. The papers summarised and integrated the FYE researchand evidence-base that existed at the time, and drew on literature from North America, the United Kingdom and Australia. The process of discussion and sharing amongst key QUTwide stakeholders based on the papers led to the emergence of three principles which have subsequently been used to guide FYE initiatives and hence the FYEP at QUT. The principles are:

P1: The first year curriculum must engage new learners in their learning and mediate support for that learning (QUT, 2002a). This is assisted by:

P2: $\quad$ Awareness of and timely access to QUT support services (QUT 2002b); and

P3: $\quad$ Creating a sense of belonging through involvement, engagement and connectedness with their university experiences (2002c).

Yorke and Longden (2008) recently analysed the literature on the student experience and found "several broad areas of institutional activity through which the chances of student success can be enhanced" (p. 4). The first two areas they identified were an institutional commitment to student learning and hence to student engagement, and proactive management of student transition. This validates the setting up of the FYEP and the implementation processes used which evidenced an obvious institutional commitment to raising the profile of and seeking to manage proactively the first year student experience. The outcome at QUT was invigorated FYE discussion and action.

As change agents across the institution pursued this agenda under principles P1 to P3, a number of themes emerged during that time as our approaches matured:

1. The identification of curricular and co-curricular ${ }^{2}$ influences on the FYE and an increasing awareness of the importance of their relationship, one to the other, and the necessity for an "organising device" to bring the two together for program coherence.

2. The realisation that an inclusive view of curriculum was the "missing link" (Kift, 2009a, p. 1) in FYE conceptualisation and that "curriculum," broadly conceived, had the potential to be the academic and social "organising device" and the "glue that holds knowledge and the broader student experience together" (McInnis, 2001, p. 11).

\footnotetext{
${ }^{2}$ Co-curricular activities are non-compulsory opportunities closely aligned to curriculum and offered by the institution/faculty/discipline to support, enhance, build on or expand the learning opportunities of the formal curriculum e.g. peer mentoring; as opposed to extra-curricular activities which are non-compulsory opportunities offered more broadly across the institution which are not closely associated with the curriculum e.g. clubs and societies.
} 
3. An emerging awareness that professional-academic partnerships across all institutional aspects were essential to the successful integration and implementation of co-curricular and curricular activities and the seamlessness of the student experience.

The research- and evidence-base and the stimuli for the evolution and maturation of associated policy and processes for each of these pivotal themes are discussed next.

\section{Building on the foundation: The evolution and maturation of a whole-of-institution approach} to FYE

\section{Integrating co-curricular and curricular learning experiences}

The research- and evidence-base harnessed at that time was successful in several ways: legitimising existing initiatives, cultivating discrete pockets of early intentional curriculum redesign, and sponsoring the appointment of a dedicated professional staff member as FYE Coordinator to oversee peer-facilitated approaches to orientation. With regards to curriculum activities, specific examples included a new information technology degree (Nelson, 2009), redesign of the first year law program (Kift, 2003, 2004), and embedding Peer Assisted Study Sessions (PASS) into selected subjects (e.g. Murray, 2006). As regards co-curricular activities, attention was paid to the training and development of first year sessional teaching staff (Kift, 2002) while, in the Orientation arena, there was a concentrated effort on "the production and uptake of a transferable orientation package to assist schools, faculties, courses or campuses to develop and administer orientation days specific to their own discipline" (QUT, 2009, p. 10). However, at this stage in the maturation of our FYE program, the functional divides between "academic" and "professional" responsibilities remained and work in both domains continued to occur in traditional isolation, with academic staff focussing on curriculum and pedagogical activities, and professional staff dealing with the development and implementation of Orientation activities and other co-curricular activities including Peer Programs. ${ }^{3}$

It was Swing's address to the $7^{\text {th }}$ Pacific Rim First Year in Higher Education Conference in 2003, in which he highlighted the "foundational dimensions" (Foundational Dimensions, 2005) for enhancing the first tertiary year, that galvanised us to work holistically towards the "joining-up" of our various well-intentioned but quite disparate and disconnected FYE initiatives. Particularly, the second of the nine dimensions in his inspired model refers to the need for organisational intent in FYE design in the following terms:

Foundations Institutions create organizational structures and policies that provide a comprehensive, integrated, and coordinated approach to the first year. These structures and policies provide oversight and alignment of all first-year efforts. A coherent first-year experience is realized and maintained through effective partnerships among academic affairs, student affairs, and other administrative units and is enhanced by ongoing faculty and staff development activities and appropriate budgetary arrangements. (Organization) (Foundational Dimensions, 2005, II 3)

\footnotetext{
${ }^{3}$ Peer Programs has been adopted as the umbrella term that describes all activities promoted or managed by QUT that involve students assisting other students. The activities range from "buddy" mentoring programs to student learning advisors, student ambassadors and orientation facilitators. The work performed by the student leaders may be paid or voluntary depending on the actual activity and the level of formalisation.
} 
The first evidence of curricular and co-curricular experiences intentionally being coordinated started to appear during 2003 in isolated disciplinary pockets (as exampled below) and when academic staff members were invited by the Director of Student Services to join the institution's First Year Experience Committee. In that setting, a group of like-minded professional and academic staff agreed to bid collaboratively for a capacity building project to articulate a blueprint for QUT's FYE that would provide the framework to implement Swing's exhortation for a "comprehensive, integrated, and coordinated approach to the first year" (Foundational Dimensions, 2005, II 3). The resulting project, Enhancing Transition at QUT (ET@QUT) (QUT, 2009) involving professional and academic staff working in partnership, has been reported in the literature (e.g. Kift \& Nelson, 2005; Nelson, Kift \& Clarke, 2008) and in a range of institutional reports (e.g. QUT, 2009). Over 2003-2005, ET@QUT explored how best to manage the various aspects of the first year student experience and life cycle (Higher Education Academy, 2001) in a proactive and integrated way. Some representative examples:

Example 1: Orientation as a process, not an event. As has now been enshrined in QUT policy since $2007,{ }^{4}$ we came early to the evidence-based realisation that Orientation should be conceptualised as a process that occurs over time, both independent of the curriculum and mediated by it. Kift (2004) reports on a "Just In Time" initiative instigated within the QUT Faculty of Law in 2003 where, across the whole of first semester, students in a first year core subject received a weekly degree-tailored email from the Assistant Dean, Learning and Teaching providing a

\begin{abstract}
staged delivery of information . . . dealing with issues such as: where to go and who to contact for Law School information; getting connected to IT and online facilities; employment opportunities; counselling services; plagiarism; Law Library and general study skills workshops; drop-in tutorial details; how to go about your tutorial presentation; confirmation that it is normal to "hit-the-wall" in about weeks 5-7; [and] a weekly study hint. (p. 12)
\end{abstract}

Example 2: Peer mentoring. A strategic outcome from the Welcome Mentoring Sub-Project of the ET@QUT project was "the production of a set of discipline specific and transferable peer mentoring resources to assist schools, faculties, courses or campuses to develop and administer peer mentoring projects within their own area" (QUT, 2009, p. 12). As appropriate, the resources developed could support an ongoing in-semester activity linked to the curriculum. This initiative was specifically designed to supplement the existing "transition/orientation buddies" process, which was a one-off Orientation activity offered for one or two days over the traditional Orientation Week event.

When we think carefully about the co-curricular touchstones of first year student successmatters such as the development of academic literacies and socio-cultural competences (Lawrence, 2005), facilitation of peer relationships, mediation of non-academic support (Australian Council for Educational Research [ACER], 2009a), provision of learning support, course and career advising, and support for staff interactions - and knowing as we do how critical these affordances are to early student learning and engagement, it is indeed difficult to think of any co-curricular activity that you would not want to drive through the curriculum. As Tinto (2009) has recently observed, "student success does not arise by chance. It is the

\footnotetext{
${ }^{4}$ QUT Manual of Policies and Procedures, C/6.2 The First Year Experience. Retrieved February 15, 2010, from http://www.mopp.qut.edu.au/C/C 06 02.jsp
} 
result of an intentional, structured, and proactive set of strategies that are coherent and systematic in nature and carefully aligned to the same goal" (p. 10). And this has implications for the way curriculum is conceptualised, which focussed our institutional thinking on the importance of curriculum, the second pivotal theme.

\section{Harnessing curriculum as the organising device}

The key and innovative feature of our maturing approach to an effective cross-institutional FYE was the realisation in our research and practice that curriculum was the "missing link" in FYE theorising. This insight was prompted in 2005 when we reflected more deeply on McInnis' (2003) statement about the challenge of bridging the institutional silos. Our response at that time was to conceptualise a "Blueprint for Enhanced Transition" (Nelson, Kift, Humphreys \& Harper, 2006) that would do that holistic "bridging" work through a managed learning environment.

\footnotetext{
Traditionally, these learning environments that seek to integrate and present "a single view" to students have been called Managed Learning Environments (MLEs). These have been described (JISC/UCISA, 2003) as a system that uses technology to enhance and make more effective the network of relationships between learners, teachers and organisers of learning through integrated support for richer communication and activities. (p. 3)
}

Though the curriculum featured heavily in this design, and as useful as an MLE was in progressing our thinking around desirable coherence and integration, a residual difficulty was that the Blueprint still only collected together discrete, siloed activities, albeit in a genuine attempt to present students with a coordinated "one-world" view. At best, it was an imposed organising device.

As we continued our efforts to translate "research and theory [and our reflective practice] into [improved] effective practice" (Tinto, 2006-2007, p. 2), we found that the organising device needed was the curriculum itself rather than some other framework. Once we came in from the periphery to examine the potential of the curriculum as an organiser, it became clear that what was required was an articulation of the favourable pedagogical "conditions, opportunities and expectations" (Coates, 2005, p. 26) to enable equitable learning engagement to occur in the first year, via the mechanism of curricular and co-curricular integration. Under this conceptualism, because it frames the first year experience for all students, the curriculum, designed intentionally, can do serious transition and retention work as McInnis's (2001) "glue ... [to hold] knowledge and the broader student experience together" (p. 11).

Internationally, mass higher education and widening participation have focussed attention on student heterogeneity and the challenges of mediating that difference in increasingly resource-poor environments. However, in all their diversity, students come to higher education with the common and legitimate expectation of being provided with the opportunity and support to learn (Nelson et al., 2008). It is our contention-and one of the fundamental beliefs underpinning the FYE at QUT - that it is within the first year curriculum that all students must be inspired, supported, and realise their sense of belonging; not only for transition, early engagement and retention (Kift \& Field, 2009; McMillan, 2005; Nora, Barlow \& Crisp, 2005; Schrader \& Brown, 2008; Trotter \& Roberts, 2006), but also as foundational for later year learning success and a lifetime of professional practice (Harvey, Drew \& Smith, 2006; Krause et al., 2005; McInnis, James \& Hartley, 2000; Reason et al., 2005, 2007; Tinto, 2001; Upcraft, Gardner, Barefoot \& Associates, 2005). Working around 
the curriculum or in aid of it, as much of the FYE work and research to that time generally had, in our opinion failed to engage with the core of the student experience - the learning experience. The renewed focus was to come in to the curriculum from the periphery to concentrate on what an intentional and holistic first year curriculum design might optimally entail.

In this work, "curriculum" is conceptualised broadly to encompass the "totality of the undergraduate student experience of, and engagement with, their new program of tertiary study" (Kift, 2009a, p. 9). "Curriculum" in this sense comprises all of the academic, social and support aspects of the student experience, focuses on the "educational conditions in which we place students" (Tinto, 2009, p. 2), and includes the co-curricular opportunities offered with which students are encouraged to engage (Kift, 2009b). "The curriculum is what students have in common, is within our institutional control, and is where time-poor students are entitled to expect academic and social support and engagement" (Kift, 2009a, p. 9). To do otherwise is to leave student success to chance (Tinto, 2009) because our responses would be bolted-on, piecemeal and de-contextualised and, from the student perspective, appear to be irrelevant to the core business of learning.

This essential curriculum focus (Kift \& Nelson, 2005) has determined QUT policy and practice since 2005 and has had a profound impact on thinking in the sector (Kift, 2009a). However, this focal shift to curriculum design is recent and new challenges have presented; for example, a 2006 review of the centrality of curriculum to the student experience found that there was

\begin{abstract}
a dearth of shared wisdom available and very few accessible case study exemplars to which innovators in this field could relate. Teachers, academic managers, and institutional learning and teaching leaders were looking for both theoretical and practical assistance in designing customised first year curriculum in response (particularly) to increasing diversity in entering cohort preparedness. The enabling of academic and professional partnerships in the pursuit of this agenda also quickly identified itself as a critical issue. [Emphasis added]. (Kift, 2009a, pp. 1-2)
\end{abstract}

We propose that intentional first year curriculum design that carefully scaffolds and mediates the first year learning experience for contemporary heterogeneous cohorts (Kift, 2005, 2008, 2009a; Kift \& Nelson, 2005; Nelson et al., 2006) can address and redress these issues.

The "critical issue" of institutional partnerships is the third pivotal theme that emerged and is now considered.

\title{
3. Facilitating cross-institutional academic and professional partnerships
}

Our awareness of the critical importance of professional and academic partnerships to the efficacy of the FYE started to crystallize at about the same time we were searching for the organising device discussed above, coordinating siloed activity and bridging the gaps not only functionally and logistically, but fundamentally, structurally and culturally. We started using the phrase "the FYE is everybody's business", quite early on to encourage buy-in and assumption of shared responsibility.

Kift (2009a) argues that individual effort around and commitment to the enhancement of the first year student experience generally, and in its curriculum dimension particularly, is necessary but not sufficient. For this work to be implemented fully, well and sustainably,

\footnotetext{
${ }^{5}$ See now this expression in QUT policy, C/6.2 The First Year Experience, at http://www.mopp.qut.edu.au/C/C 06 02.jsp
} 
institutional players must integrate and coordinate their various excellent, but often quite disparate, first year initiatives and work together to transcend the silos of academic, administrative and support areas (McInnis, 2003) to enact a holistic, systematically-managed, vision for the FYE that is truly student-focussed and is indeed greater than the sum of its many parts (Kift, 2009a).

While this work is challenging and difficult (Kift, 2009a; McInnis, 2003), it is plainly the key to institutional effectiveness in the promotion and assurance of the learning and success of students in transition, as the John N. Gardner Institute for Excellence in Undergraduate Education (previously the Policy Center on the First Year of College, Brevard College) has found after years of research (Foundational Dimensions, 2005). And it is possible to rise to the challenge and enact interventions which have extremely positive outcomes of benefit to student FYE, as the following two examples demonstrate.

Example 1: Cross-institutional assurance of peer mentoring. In 2006, working with academic and professional colleagues across the university, at QUT

\begin{abstract}
we were able to identify all the many and varied peer-to-peer opportunities that students have available to them across [the institution] and to bring the staff directing those programs and practices together with a view both to validating this previously unrecognised work and to enabling a consistent look and feel to all these various initiatives in a way that makes sense to students and is student-facing (e.g., by way of standardised mentor reward and recognition, common T-Shirts and branding, sharing and up-scaling of practice across organisational areas, etc.). This process is now being very effectively managed and sustainably coordinated by the Head of QUT’s Counselling Services. (ET@QUT sub-project, reported in Kift, 2008, p. 9).
\end{abstract}

Example 2: Facilitating student agency in the administration of their learning. In 2005 at QUT, pedagogical and administrative imperatives brought to fruition an academic and professional staff initiative that saw the design and deployment of a web-based transition portal to provide a personalised, one-world, student view of all their potential interactions with the institution-academic, administrative and support (Nelson, Kift \& Harper, 2005). The web-based digital interface was designed with specific regard for the characteristics and skills of commencing students in particular and their preferences for use and interaction with technology in support of their learning. Functionally, the portal had five key elements, each of these with a drill down, store and archive capability:

- An individual student calendar;

- A message portlet (unit specific academic messages as well as critical date administrative messages);

- Access to student selected resources (e.g. discussion forums);

- Direct access to the QUT Learning Management System (LMS) for unit materials, resources and learning activities; and

- The most recent emails sent from a QUT address.

This intervention, which was unique in the sector at the time of its implementation, was a significant portent of the transformative power that coordinated cross-institutional partnerships, once exploited, could have on the student experience. 


\title{
Summarising the evolution
}

Around a decade ago, commencing students' at QUT relied on an ad hoc collection of siloed and often covert experiences offered by dedicated but isolated academic and/or professional staff. Based on (i) the foundation of institutional support for and commitment to an FYEP, (ii) an integration of FYE policies and associated practices and (iii) the involvement of an ever-increasing number of dedicated academic and professional staff, this has evolved and matured into a situation where QUT now has an environment which provides the potential for commencing students to achieve engagement, timely access to support and the development of a strong sense of belonging. This is made possible by the bringing together of co-curricular and curricular strategies into an intentionally designed and broadly conceptualised curriculum; one which is implemented through the shared knowledge and skills of partnered academic and professional staff in an institutional environment that is committed to an optimal first year experience both at the policy and practice levels.

\section{Some terminology}

Discussion of evolving FYE research and practice has been facilitated by Wilson's (2009) notion of "generations" of FYE approaches. In this classification, first generation approaches have tended to focus on co-curricular initiatives - strategies such as support services, learning support, orientation and peer programs, academic advising, social activities, enrichment programs (Wilson, 2009, p. 10). There is general agreement across the sector nationally and internationally as to what constitutes co-curricular activities and hence a first generation approach. Although there is also consensus that second generation approaches focus on curriculum, this has been variously articulated. Wilson (2009) presents the second generation approach as consisting of specific curriculum-related activities and strategies: "the core practices of education (e.g., teaching quality, course design, etc.) [with] common examples including engaging course and assessment design, formative assessment tasks, and community building in the classroom" (p. 10). We, on the other hand and as explored above, focus more explicitly on an integrated holistic approach; intentionally blended curricular and co-curricular (broadly "curriculum" in our conceptualisation) with a "focus squarely on enhancing the student learning experience through pedagogy, curriculum design, and learning and teaching practice in the physical and virtual classroom" (Kift 2009a, p. 1).

The third generation approach is characterized by Lizzio (2009) as "a coordinated whole of institution partnership and consistent message about the first year experience across the university" (p. 14) but perhaps more explicitly and operationally by Kift (2009a):

\begin{abstract}
A third generation FYE approach is a further collaborative and strategic leap again that requires whole-of-institution transformation. This optimal approach will only occur when first generation co-curricular and second generation curricular approaches are brought together in a comprehensive, integrated, and coordinated strategy that delivers a seamless FYE across an entire institution and all of its disciplines, programs, and services. Third generation strategies will require an institutional vision for the FYE that is shared by academic and professional staff who form sustainable partnerships across institutional boundaries to ensure its enactment. (p. 1)
\end{abstract}

The latter definition is consistent with the current evolved state of maturity of FYE at QUT and is what we have previously theorized as "transition pedagogy" (Kift \& Nelson, 2005). 


\section{Transition pedagogy}

We have argued here that an optimal FYE should be framed around intentional first year curriculum design that carefully scaffolds, mediates and supports first year learning for contemporary heterogeneous cohorts (Kift, 2005, 2008, 2009a, 2009b; Kift \& Nelson, 2005; Nelson et al., 2006). An "intentional curriculum" in this regard is one that endeavours, deliberately and explicitly, to create that optimal FYE as a one-world view from the studentfacing perspective and is implemented through the seamless involvement of professional and academic staff. This can be achieved by identifying the favourable conditions that underpin seamless curricular and co-curricular design and using these to develop an organising framework for maximal interpretation. Under a transition pedagogy, such an organising framework for policy and practice has been articulated under an Australian Learning and Teaching Council (ALTC) Senior Fellowship (Kift, 2008, 2009a, 2009b) as a set of interconnected curriculum principles that stand out in the research as supportive of first year learning engagement, success, and retention across all disciplines. These have been labelled the First Year Curriculum Principles (FYCPs) and a detailed discussion of their development, trialling, operationalisation, and evaluation is available elsewhere (Creagh, Nelson \& Clarke, 2010; Duncan et al., 2009; Kift, 2008, 2009a, 2009b). The FYCPs have been rigorously evaluated by the higher education community, nationally and internationally, under the auspices of the ALTC Senior Fellowship and feedback received has indicated the sector's overwhelming acceptance of their validity, and acknowledgement of their flexibility and applicability across contexts and delivery modes (Kift, 2009a). Suffice to say the principlesTransition, Diversity, Design, Engagement, Assessment, and Evaluation \& Monitoringbecome that organising framework when explicitly and intentionally deployed to facilitate student engagement, mediate learning support and address the development of discipline knowledge and learning skills which are contextualised and embedded through the curriculum.

This integration of strategies and principles as transition pedagogy is summarised in Figure 1.

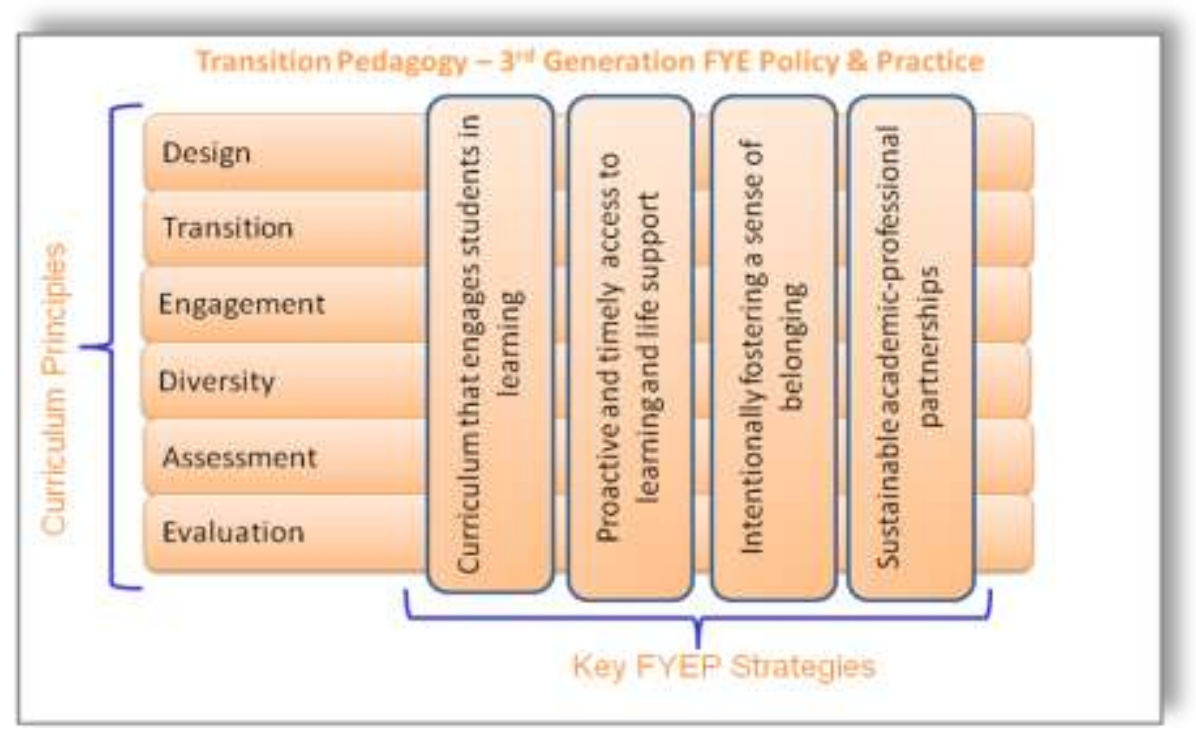

Figure 1 Transition pedagogy - Conceptual model 
Such an appropriately designed transition pedagogy answers Krause and her colleagues' (2005) call for more holistic and sustainable institution-wide approaches and enhancements. Specifically in this regard, a transition pedagogy and the six FYCPs which frame its implementation,

- are research-based but move desirably from theory to action;

- have been conceived to help guide and inform practice;

- are supported by practical tips, checklists, examples, and strategies for implementation to move from principle to practice, all of which are now available on a dedicated Transition Pedagogy website; ${ }^{6}$

- have been rigorously evaluated by the higher education community under the auspices of the ALTC Fellowship and are evidence-based (Kift, 2009a); and

- are congruent with existing theoretical and research-based frameworks addressing optimal FYE (e. g. Foundational Dimensions, 2005).

\section{Discussion}

Why is Transition Pedagogy important?

The social justice case

Forty percent of QUT students are the first in their family to attend university. They have complex lives which include working off-campus for $10 \%$ more time than their peers nationally, spending on average six hours per week travelling to and from classes, spending less time on classes and relying heavily on learning technologies to provide anytime, anywhere access to course and learning materials. Approximately 33\% of all QUT students belong to one or more equity groups with the largest concentrations being students from rural and regional backgrounds (19\%) and low socio-economic status backgrounds at (14\%) (ACER, 2009b; James, Krause \& Jennings, 2010). In the next five years, it is likely that the diversity of the student cohort at QUT and other institutions will increase as HEIs respond to the federal government's widening participation agenda. A transition pedagogy intentionally and proactively takes account of and seeks to mediate the reality of commencing cohorts diverse in preparedness and cultural capital. The concern is that, if we do not harness and centralise the curriculum in the student experience, student take-up of our otherwise disparate and piecemeal efforts to support their FYE is left to chance. In the face of increasing diversity, equal opportunity for success delivered through the curriculum is within our institutional control and, quite simply, is our legal and moral responsibility. As Tinto (2008) states:

\footnotetext{
Nowhere does such restructuring matter more than during the critical first year of [university] when student success is so much in doubt. It is for that reason that there is much to be gained from a rethinking of the character of the first year and the development of coherent and carefully aligned first-year programs whose purpose it is to ensure that all students, especially those from low-income backgrounds, are able to learn and persist beyond that year. (p. 9)
}

Transition pedagogy in action delivers Tinto's fundamental "restructuring" and essential "rethinking of the character of the first year"; coherent and careful alignment of institutional

\footnotetext{
${ }^{6}$ See Transition Pedagogy website at http://www.fyhe.qut.edu.au/transitionpedagogy/; see also the range of materials available to support FYE enhancement on the First Year in Higher Education website at http://www.fyhe.qut.edu.au/
} 
activities to ensure that all students, whatever their entering backgrounds, are provided with every opportunity to access equitably the transformative effects of higher education. That is, transition pedagogy reflects a coherent, integrated, coordinated policy and practice in support of the FYE.

\title{
The economic case
}

A recent study of retention for the Australian sector (Adams, Banks, Davis \& Dickson, 2010) has estimated the total cost of attrition to be in the realm of $\$ 1$ billion per annum or $\$ 20-\$ 36$ million for each of the 38 public universities. An analysis of the impact on student retention for one key FYEP strategy confirms this for the QUT context. Marrington, Nelson and Clarke (2010) have assessed the economic impact of the Student Success Program (SSP) (Nelson, Duncan \& Clarke, 2009) at QUT, an intervention designed to identify and support first year students classified as at-risk of not engaging with or disengaging from QUT. The program has been shown to be successful in preventing at risk students from dropping out and, in a follow-up study (Nelson, Marrington \& Clarke, in process), to be still enrolled one year later. Marrington et al. (2010), using data from a cohort of 469 students in only one faculty, found that the SSP's intervention in the students' first year, caused 75 students in that cohort who would otherwise not be enrolled to be still enrolled by the end of second year. This represents retained income of over $\$ 1.8$ million across a three year degree. ${ }^{7}$

A properly implemented transition pedagogy - one that optimises the opportunity for student engagement, provides timely access to support and the development of a strong sense of belonging - has characteristics similar to the SSP intervention (for details of the latter, see Nelson et al., 2009). Consequently, it seems reasonable to assume that transition pedagogy in action would be of considerable economic benefit to an institution.

\section{The importance of the synchronicity of policy and practice}

In 2008, Kift posed the challenge:

\begin{abstract}
How might all the institutional players integrate and coordinate their various excellent, but quite disparate, first year initiatives and work together towards more holistic and sustainable, institutionwide, approaches that transcend the silos of academic, administrative and support areas? (p. 1)
\end{abstract}

In answer to this challenge, Kift (2008) advocated the "tried and true 'top-down, bottom-up' approach for intentional action." Starting from the "bottom-up" suggests that institutions need first "to identify and then coordinate individual, dispersed FYE efforts to ensure sustainability and coherence of initiatives across its organisational areas" (p. 2). Building on this ground-up approach, "a model for institutional action may then be promoted, which can focus [top-down] commitment to an enduring FYE culture as an institutional priority that is, both in rhetoric and reality, 'everybody's business"' (p. 3).

This was the model used at QUT. A fundamental reason for the successful evolution of the third generation transition pedagogy at QUT was the synchronous relationship between FYE policy development and its enshrinement in QUT policy ("top down") and the development and implementation of associated strategies and resources by academic and professional staff responsible for the students' FYE ("bottom up"). Buy in and a sense of ownership by staff was essential-FYE is everybody's business. Mandated policy and associated rhetoric alone

\footnotetext{
${ }^{7}$ See Marrington et al. (2010) for details of costings and calculations.
} 
or strategy and resource development without institutional recognition and policy support just would not work.

\title{
Transition pedagogy is hard work
}

Consistent with Swing's (2003) prediction, it is almost a decade since serious attention was focussed on the FYE at QUT and the current position is the outcome of a large amount of consistent and hard work over that period. It is not surprising then that Kift (2009a) reported that institutions in general are struggling with whole-of-institution integration, coordination, and coherence and concluded that

\begin{abstract}
learning leadership ... and coherent governance structures are critical in this regard to identify, harness, and upscale existing goodwill and practice and to enable partnerships with the capability to work across and within existing organisational structures and processes, both academic and professional, to create a shared vision of the FYE as "everybody's business." (p. 13)
\end{abstract}

Unless whole-of-institution conversations and interactions are facilitated and determined efforts are made to coordinate and mainstream otherwise disparate and disconnected initiatives, the potential for positive impact of well-intended FYE strategies will be limited by perceptions of role capability. In the absence of institutional commitment to take first year student education and retention seriously (Tinto, 2009), all too frequently the coalface FYE reality can be "quite bleak" (Kift, 2009a, p. 14). However, where institutional policy and commitment are matched by seamless academic-professional staff cooperation and congruent practices, transition pedagogy can be successfully enacted.

\section{Conclusion}

This discussion, drawing on close to a decade of FYE-related research and evidence at QUT, has traced the evolution and maturation of policy and strategies that ultimately focussed on achieving cross-institutional integration, coordination and coherence of FYE policy and practice and interpreted FYE as "everybody's business." In so doing, we have conceptualized transition pedagogy as a third generation approach ${ }^{8}$ to FYE where student engagement, their timely access to support and the development of a strong sense of belonging are achieved by bringing together co-curricular and curricular strategies into an intentionally designed and broadly interpreted curriculum, operationalised through the FYCPs, that is implemented through the shared knowledge and skills of partnered academic and professional staff in an institutional environment that is committed to an optimal FYE at the policy, resource and practice levels. Transition pedagogy transcends the silos of academic, administrative and support areas to enact a holistic, systematically-managed, vision for the FYE that is truly student-focussed. Because of the centrality of curriculum to this process and that curriculum is what all students have in common, irrespective of their diversity, and is within our

\footnotetext{
${ }^{8}$ As useful as the "generation" classification has been to conceptualising FYE, we are currently exploring the application of the Capability Maturity Model to FYE (Paulk, Weber, Curtis \& Chrissis, 1995).The model consists of five maturity levels or evolutionary stages through which an entity - in our case the FYE-matures or evolves from ad hoc possibly chaotic processes to mature disciplined processes with, at each new level, new and improved processes being added to those implemented at earlier levels. That model is currently under development.
} 
institutional control, transition pedagogy can cater for heterogeneous cohorts, a fixture on the contemporary and future higher education scene. 
Transition Pedagogy: A third generation approach to FYE - A case study of policy and practice for the higher education sector

\section{References}

Adams, T., Banks, M., Davis, D. \& Dickson, J. (2010). The Hobsons retention project: Context report. Not yet publically available.

Australian Council for Educational Research. (2009a). Engaging students for success. Australasian student engagement report. Australasian Survey of Student Engagement. Retrieved June 10, 2009, from http://www.acer.edu.au/documents/AUSSE_2008StudentEngagementReport.pdf

Australian Council for Educational Research. (2009b). AUSSE Queensland University of Technology Executive Summary Report. Not yet publically available.

Bradley, D., Noonan, P., Nugent, H. \& Scales, B. (2008). Review of Australian higher education. Final report. Canberra, Australia: Commonwealth of Australia. Available at

http://www.deewr.gov.au/HigherEducation/Review/Pages/ReviewofAustralianHigher EducationFinalReport.aspx

Coates, H. (2005). The value of student engagement for higher education quality assurance. Quality in Higher Education, 11(1), 25-36.

Creagh, T. A., Nelson, K. J. \& Clarke, J. A. (2010, June). The development of a "Good Practice Guide" for first year curriculum development, revision and evaluation - a moving feast. A "Nuts and Bolts" presentation at the $13^{\text {th }}$ Pacific Rim First Year in Higher Education Conference, "Aspiration-Access-Achievement." Adelaide, Australia. Available http://www.fyhe.com.au/past_papers/papers10/content/pdf/11A.pdf

Duncan, M., Quinn, C., Nelson, K. J., Smith, J. E., Creagh, T. \& Clarke, J. A. (2009, June). Operationalising first year curriculum principles. A "Nuts And Bolts" presentation at the $12^{\text {th }}$ Pacific Rim First Year in Higher Education Conference, "Preparing for Tomorrow Today: The First Year Experience as Foundation." Townsville, Queensland. Available

at http://www.fyhe.com.au/past_papers/papers09/content/pdf/6C.pdf

Foundational Dimensions. (2005). Foundational Dimensions ${ }^{\circledR}$ (Four-year college version). John N. Gardner Institute for Excellence in Undergraduate Education. Retrieved February 20, 2010, from http://www.fyfoundations.org/4year.aspx

Gillard, J. (2010). Address to the Universities Australia annual higher education conference. Retrieved May 28, 2010, from http://www.deewr.gov.au/Ministers/Gillard/Media/Speeches/Pages/Article_100303_1 $\underline{02842 . a s p x}$

Harvey, L., Drew, S. \& Smith, M. (2006). The first year experience: A literature review for the Higher Education Academy. Retrieved September 3, 2007, from http://www.heacademy.ac.uk/assets/York/documents/ourwork/research/literature_revi ews/first_year_experience_full_report.pdf

Higher Education Academy. (2001). Strategies for widening participation in higher education. Higher Education Funding Council for England (HEFCE) Guide 01/36. Retrieved February 15, 2010, from http://www.hefce.ac.uk/Pubs/HEFCE/2001/01_36.htm

James, R., Krause K-L. \& Jennings, C. (2010). The first year experience in Australian universities: Findings from 1994 to 2009. Melbourne, Australia: Centre for Studies in Higher Education, The University of Melbourne..

Kift, S. M. (2002, July). Assuring quality in the casualisation of teaching, learning and assessment: Towards best practice for the first year experience. Paper presented at the 
$6^{\text {th }}$ Pacific Rim First Year in Higher Education Conference, "Changing Agendas 'Te Ao Hurihuri'." Christchurch, New Zealand. Retrieved February 15, 2010, from http://www.fyhe.com.au/past_papers/abstracts02/KiftAbstract.htm

Kift, S. M. (2003, July). First year renewal to engage learners in Law. Paper presented at the $7^{\text {th }}$ Pacific Rim First Year in Higher Education Conference, "Enhancing the Transition to Higher Education." Brisbane, Australia. Retrieved February 15, 2010, from http://www.fyhe.com.au/past_papers/papers03/Refereed\%20Papers/Transition\%20\& \%20Adjustment/Kift_ab.doc

Kift, S. M. (2004, July). Organising first year engagement around learning: Formal and informal curriculum intervention. Paper presented at the $8^{\text {th }}$ Pacific Rim First Year in Higher Education Conference, "Dealing with Diversity." Melbourne, Australia. Retrieved February 20, 2010, from http://www.fyhe.com.au/past_papers/Papers04/Sally\%20Kift_paper.doc

Kift, S. M. (2005, April). Transforming the first year experience: A new pedagogy to enable transition. Paper presented at the Enhancing Student Success Conference, University of Newcastle. Retrieved March 4, 2009, from http://www.ccc.newcastle.edu.au/studentsupport/2005conference/Sally\%20Kift.pdf

Kift, S. M. (2008, June). The next, great first year challenge: Sustaining, coordinating and embedding coherent institution-wide approaches to enact the FYE as "everybody's business." Keynote address presented at the $11^{\text {th }}$ Pacific Rim First Year in Higher Education Conference, "An Apple for the Learner: Celebrating the First Year Experience." Hobart, Australia. Retrieved March 4, 2009, from http://www.fyhe.qut.edu.au/past_papers/papers08/FYHE2008/content/pdfs/Keynote\% 20-\%20Kift.pdf

Kift, S. M. (2009a). Articulating a transition pedagogy to scaffold and to enhance the first year student learning experience in Australian higher education. Final Report for ALTC Senior Fellowship Program. ALTC Resources. Retrieved February 7, 2010, from http://www.altc.edu.au/resource-first-year-learning-experience-kift-2009

Kift, S. M. (2009b, February). A transition pedagogy for first year curriculum design and renewal. Paper presented at the FYE Curriculum Design Symposium 2009, Queensland University of Technology, Brisbane, Australia. Retrieved February 15, 2010, from http://www.fyecd2009.qut.edu.au/resources/PRE_SallyKift_5Feb09.pdf

Kift, S. M. \& Field, R. (2009, June). Intentional first year curriculum design as a means of facilitating student engagement: Some exemplars. Paper presented at the $12^{\text {th }}$ Pacific Rim First Year in Higher Education Conference, "Preparing for tomorrow today: The first year experience as foundation." Townsville, Australia. Available at http://www.fyhe.com.au/past_papers/papers09/content/pdf/16D.pdf

Kift, S. M. \& Nelson, K. J. (2005). Beyond curriculum reform: Embedding the transition experience. In Brew, A. \& Asmar, C. (Eds.), Higher Education in a changing world: Research and Development in Higher Education (pp. 225-235). Milperra, NSW: HERDSA.

Krause, K-L., Hartley, R., James, R. \& McInnis, C. (2005). The first year experience in Australian universities: Findings from a decade of national studies. Canberra, Australia: Australian Department of Education, Science and Training. Retrieved February 24, 2009, from http://www.griffith.edu.au/_data/assets/pdf_file/0006/37491/FYEReport05.pdf

Kuh, G. (2007, June). What matters to student success in the first year of university. Keynote address at the $10^{\text {th }}$ Pacific Rim First Year Experience in Higher Education Conference, "Regenerate-Engage-Experiment." Brisbane, Australia. Retrieved 
Transition Pedagogy: A third generation approach to FYE - A case study of policy and practice for the higher education sector

February

20 ,

2010 ,

from

http://www.fyhe.com.au/past_papers/papers07/fullprogram2.html

Lawrence, J. (2005, July). Addressing diversity in higher education: Two models for facilitating student engagement and mastery. Paper presented at the HERDSA Conference 2005: Higher Education in a Changing World, Sydney, Australia.

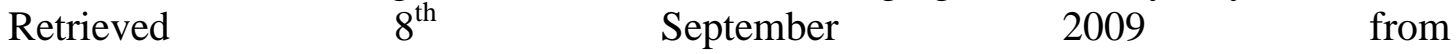
http://conference.herdsa.org.au/2005/pdf/refereed/paper_300.pdf

Lizzio, A. (2009). Ensuring a successful transition to first year. Communique, 2, 14.

Marrington, A., Nelson, K. J. \& Clarke, J. A. (2010, June). An economic case for systematic student monitoring and intervention in the first year in higher education. A "Nuts and Bolts" presentation at the $13^{\text {th }}$ Pacific Rim First Year in Higher Education Conference, "Aspiration-Access-Achievement." Adelaide, Australia. Available at http://www.fyhe.com.au/past_papers/papers10/content/pdf/6D.pdf

McInnis, C. (2001). Signs of disengagement? The changing undergraduate experience in Australian universities. Melbourne, Australia: Centre for Studies in Higher Education. Retrieved March 4, 2009, from http://repository.unimelb.edu.au/10187/1331

McInnis, C. (2003, August). New realities of the student experience: How should universities respond? Paper presented at the $25^{\text {th }}$ Annual Conference of the European Association for Institutional Research, Limerick, Ireland.

McInnis, C., James, R. \& Hartley, R. (2000). Trends in the first year experience in Australian universities. Department of Education, Training and Youth Affairs. Retrieved August 28 , 2006,

from http://www.dest.gov.au/archive/highered/eippubs/eip00_6/execsum.htm

McMillan, J. (2005). Course change and attrition from higher education. Longitudinal Surveys of Australian Youth: Research Report No. 40. Camberwell, Australia: Australian Council for Educational Research.

Murray, M. (2006, July). PASS: Primed, persistent, pervasive. Paper presented at the 2nd National PASS Day Conference, Griffith University: Gold Coast, Australia. Retrieved February 15, 2010 from http://www.uow.edu.au/content/groups/public/@web/@stsv/documents/doc/uow0215 12.pdf

Nelson, K. J. (2009). Information Technology case study. Transition pedagogy symposium as part of the ALTC Senior Fellowship program. Retrieved February 24, 2010, from http://www.fyhe.qut.edu.au/transitionpedagogy/casestudies/informationt.jsp

Nelson, K. J., Duncan, M. \& Clarke, J. A. (2009). Student success: The identification and support of first year university students at risk of attrition. Studies in Learning, Evaluation, Innovation and Development, 6(1), 1-15.

Nelson, K. J., Kift, S. \& Clarke, J. A. (2008, June). Expectations and realities for first year students at an Australian university. Paper presented at the $11^{\text {th }}$ Pacific Rim First Year in Higher Education Conference, "An Apple for the Learner: Celebrating the First Year Experience." Hobart, Tasmania. Available at http://www.fyhe.qut.edu.au/past_papers/papers08/FYHE2008/content/pdfs/6a.pdf

Nelson, K. J., Kift, S. M. \& Harper, W. (2005, December). "First portal in a storm": A virtual space for transition students. Paper presented at ASCILITE 2005, Queensland University of Technology, Brisbane, Australia. Retrieved February 15, 2010 from http://eprints.qut.edu.au/3943/1/3943_1.pdf

Nelson, K. J., Kift, S. M., Humphreys, J. \& Harper, W. (2006, July). A blueprint for enhanced transition: Taking an holistic approach to managing student transition into a large university. Paper presented at the $9^{\text {th }}$ Pacific Rim First Year in Higher Education 
Conference,."Engaging Students." Gold Coast, Australia. Retrieved February 15, 2010 from http://www.fyhe.com.au/past_papers/2006/Papers/Kift.pdf

Nelson, K. J., Marrington, A. \& Clarke, J. A. (in process). Student success: Some further evidence two years on. Document in preparation.

Nora, A., Barlow, E. \& Crisp, G. (2005). Student persistence and degree attainment beyond the first year in college: The need for research. In A. Seidman (Ed.), College student retention: Formula for student success (pp. 129-154). Westport CT: American Council on Education.

Paulk, M. C., Weber, C. V., Curtis, B. \& Chrissis, M. B. (1995). The Capability Maturity Model for software: Guidelines for improving the software process. SEI Series in Software Engineering. Boston: Addison-Wesley.

Queensland University of Technology. (2002a). First year experience program. Issues paper 1: Engaging learning experiences. Brisbane, Australia: Author. Retrieved September 8 , 2008 , from http://www.studentsupport.qut.edu.au/information/fyeprogram/FYEPaper1.pdf

Queensland University of Technology. (2002b). First year experience program. Issues paper 2: Awareness of and timely access to support services. Brisbane, Australia: Author. Retrieved September 8, 2008, from http://www.studentsupport.qut.edu.au/information/fyeprogram/FYEPaper2.pdf

Queensland University of Technology. (2002c). First year experience program. Issues paper 3: A sense of belonging. Brisbane, Australia: Author. Retrieved September 8, 2008, from http://www.studentsupport.qut.edu.au/information/fyeprogram/FYEPaper3.pdf

Queensland University of Technology. (2008). QUT Blueprint. Retrieved February 20, 2010, from http://www.qut.edu.au/about/university/pdf/qut_blueprint_2008.pdf

Queensland University of Technology. (2009).ET@QUT Final Report. Brisbane, Australia: Author.

Reason, R. D., Terenzini, P. T. \& Domingo, R. J. (2005). First things first: Developing academic competence in the first year of college. Research in Higher Education, 47(2), 149-175.

Reason, R. D., Terenzini, P. T. \& Domingo, R. J. (2007). Developing social and personal competence in the first year of college. The Review of Higher Education, 30(3), 271299.

Schrader, P. G. \& Brown, W. (2008). Evaluating the first year experience: Students' knowledge, attitudes, and behaviors. Journal of Advanced Academics, 19(2), 310-343.

Swing, R. L. (2003, June). First-year student success: In search of best practice. Keynote address presented at the 7th Pacific Rim First Year in Higher Education Conference, "Enhancing the Transition into Higher Education." Brisbane, Australia.

Tinto, V. (2001). Rethinking the first year of college. Higher Education Monograph Series, Syracuse University.

Tinto, V. (2006-2007). Research and practice of student retention: What next? Journal of College Student Retention, 8(1), 1-19.

Tinto, V. (2008, November). Access without support is not opportunity. Paper presented at the 36th Annual Institute for Chief Academic Officers, The Council of Independent Colleges. Seattle, Washington.

Tinto, V. (2009, February). Taking student retention seriously: Rethinking the first year of university. Paper presented at the FYE Curriculum Design Symposium 2009, Queensland University of Technology, Brisbane, Australia. Retrieved March 4, 2009, from http://www.fyecd2009.qut.edu.au/resources/SPE_VincentTinto_5Feb09.pdf 
Trotter, E. \& Roberts, C. (2006). Enhancing the early student experience. Higher Education Research and Development, 25(4), 371-386.

Upcraft, M. L., Gardner, J. N., Barefoot, B. O. \& Associates (Eds.). (2005). Challenging and supporting the first-year student: A handbook for improving the first year of college. San Francisco: Jossey-Bass.

Wilson, K. (2009, June). The impact of institutional, programmatic and personal interventions on an effective and sustainable first-year student experience. Keynote address presented at the $12^{\text {th }}$ Pacific Rim First Year in Higher Education Conference, "Preparing for Tomorrow Today: The First Year Experience as Foundation." Townsville, Australia. Retrieved July 31, 2009, from http://www.fyhe.qut.edu.au/past_papers/papers09/ppts/Keithia_Wilson_paper.pdf

Yorke, M. (2006, June). Student engagement: deep, surface or strategic? Keynote address at the $9^{\text {th }}$ Pacific Rim First Year in Higher Education Conference, "Engaging Students." Gold Coast, Australia. Retrieved February 24, 2009, from http://www.fyhe.qut.edu.au/past_papers/2006/program.html

Yorke, M. \& Longden, B. (2008). The first-year experience of higher education in the UK: Final Report. York, UK: Higher Education Authority. Retrieved February 15, 2010, from http://www.heacademy.ac.uk/assets/York/documents/resources/publications/FYEFinalReport . .pdf 